\title{
"PLANTÃO DA CIDADE": a study of local political participation and the constitution of subjectivities through Facebook
}

"PLANTÃO DA CIDADE": um estudo da participação política local e constituição de subjetividades por meio do Facebook

"PLANTÃO DA CIDADE": Un estudio de la participación política local y la constitución de subjetividades a través de Facebook

\section{Hila Rodrigues}

$\mathrm{PhD}$ in Social Sciences from Universidade Federal de Minas Gerais (UFMG). Professor at Programa de PósGraduação em Comunicação at Universidade Federal de Ouro Preto (UFOP). hila.rodrigues@ufop.edu.br.

0000-0001-9277-8757

\section{Isabela Melo}

Master's in Comunicação from Universidade Federal de Ouro Preto (UFOP). melo.isabela02@gmail.com.

\section{0-0001-9371-0623}

Mailing address: Instituto de Ciências Sociais Aplicadas (ICSA). Rua do Catete, 166 - Centro. CEP 35420-000 Mariana, MG, Brasil.

Received: 10.12 .2020

Accepted: 11.20 .2020

Published: 01.01.2021.

\begin{abstract}
:
The purpose of this article is to discuss the act of political participation by citizens mediated by communication technologies. It is an effort to understand the potential scenarios and paths for the promotion of citizen participation in the sphere of public power. The investigation took place through the observation of a specific space on Facebook: the Plantão da Cidade group, conceived in the municipality of Ouro Preto to enable political discussions. The proposed exam highlights the possibilities offered by the online environment to ensure the political participation of ordinary people in municipal management decisions and the mobilization of local community actions.

KEYWORDS Citizenship. Deliberation. Facebook. Political participation. Social networks.
\end{abstract}

\section{Introduction}

The communication technologies that provide shape and dynamics to the online social networks, such as Facebook, Twitter and Instagram, offer many possibilities of interaction in numerous places around the world. In the context of social practices, these networks allow and stimulate the emergence of new modes of relationship and production of meaning, also establishing renewed sociability standards. In addition to that, they are platforms that are proven more and more useful in the field of politics - as much to public institutions as to the ordinary citizen.

A significant part of the studies on political participation and the Internet indicate that the digital environment opens up effective paths for the communication between citizens and the public authorities. Scholars who pay attention to this field of research such as Rousiley Maia (2008), Wilson Gomes (2005), Rodrigo Carreiro (2017) and Samuel Barros (2019) - seek to discuss, from various perspectives and empirical objects, the social effects of this type of communication. It is an effort to understand the potentialities, but also the limitations of these processes of interaction, exchanges and conversation. 
In dialogue with this literature, this article is guided by specific reflections on society, politics and communication. We turned our gaze to a regional scenario and, from this place, analyzed a specific group on Facebook, called "Plantão de Ouro Preto" (Ouro Preto's Watch). As the name indicates, the group is composed of citizens that live in Ouro Preto - a county that is $96 \mathrm{~km}$ distant from the capital, located in one of the main areas of the brazilian gold cycle Brazil and the first brazilian site to be considered a World Heritage Site by UNESCO. The group uses this platform to discuss sociopolitical and cultural topics that may involve common interests. In this environment, participants gain visibility and, often, influence the decisions made by the public authorities that are part of the local governmental sphere.

Bearing in mind that the exercise of politics is not depleted at party and electoral disputes - nor are they only limited to institutional spaces - the idea is to target these online environments as a space capable of providing important political debates proposed (and welcomed) by the residents of Ouro Preto. By attracting citizens that show interest in exposing issues of collective interest, the "Plantão da Cidade" opens curious paths to the debate of complex subjects involving the social policies implemented by the municipal public sector and the behavior of the population itself, when facing decisions taken within the institutional spheres.

\section{Online political participation}

Communication technologies influence how individuals assimilate the realities they experience, but not only those. They mainly influence how people place themselves, in regard to the way public authorities manage their lives. This is a phenomenon especially highlighted by scholars who have dedicated themselves to observing the processes of political conversation in digital environments. This type of citizen participation - which, coming precisely from the conversation, allows an increase in the visibility of the themes posed and the dissemination of varied contents - contributes to an extension of the points of view that cross the citizens' day-to-day lives as well as public authorities'. At the same time, it contributes to the resignification of everyday experiences.

All this is unveiled in the adopted standings and in the ideas recommended by the subjects who participate of the conversation. These are acts of political participation that can be taken, within this perspective, as "social activities designed, by the state or by civil society, so that citizens interfere in the political decision-making process." (MATOS; BARROS, CARREIRO, 2019, p.204). It is also under this aspect that Venício Lima (2017) considers as timely the communication technologies provided to citizens in the 
last decades. In his work of rereading the concept of "culture of silence" built by Paulo Freire (1921-1997), he observes that, although internet access is not yet guaranteed to all portions of the brazilian population, social networks are, currently, channels that impressively facilitate the propagation of the common citizen's voice and also his vision about the public power's decisions and deliberations.

This is a conception similar to Wilson Gomes's (2008), when asking himself what the Internet can do for political participation, after all. One finds, within this approach, that the structural and circumstantial characteristics of digital media are capable of ensuring this type of participation, contributing, from that point, to the strengthening of democratic regimes - especially in the brazilian context, which is permeated by crisis and by the fall in the credibility of political representatives. To Gomes, the Internet provides the overcoming of time and space limits for political participation, in addition to a certain convenience and extension of access.

Within public institutions - and especially in parliaments - the internet has caused and boosted, in recent years, the emergence of various digital democracy ${ }^{1}$ initiatives. This universe includes forums, institutional applications, public consultations and the production of legislative matters with the aid of digital technologies, besides the use of online environments for public deliberation processes. To Marques (2011), the deliberation should be understood here as a discursive activity that is part of a social communication process. It is not restricted, therefore, to the exchange of rational arguments or to a single moment of decision-making. In this perspective, one reveals a communicative process, in which different actors, from their respective discourses, establish a dialogue with the objective of understanding a common problem that is on the agenda. In this sense, the movement towards the other involves two important dimensions of the use of language: affective and reflexive. The first one is focused on the socialization's ludic game and the second one on institutionalized issues and standards of collective interest. (MARQUES, 2011). Both are especially present in the political conversations observed at online environments.

\section{Online political conversation as a social practice}

In the Facebook group "Plantão da Cidade de Ouro Preto", the political conversation strongly carries this cognitive affective dimension, characterized by

\footnotetext{
1 The concept of digital democracy is understood as "the use of digital technologies of communication with the purpose of correcting, increasing or incorporating new procedures into the political process, so as to better meet one or more principles of democracy". (GOMES, 2011, p.27-28).
} 
expressions of emotion, daily life narratives and testimonies that have a common mark of urgency: to place the collectivity's themes of interest on the agenda. Ângela Marques (2011) observes that this type of conversation emerges in the online universe, whenever individuals and groups understand that a particular issue "deserves to be discussed collectively, in order to seek a reciprocal understanding of the problem in question" ( $p$. 20).

At this point, it is important to note that, although this conversation has a sociopolitical nature, it is far beyond merely partisan topics (or topics that may involve electoral disputes). It mainly concerns the needs, interests and dreams of a society that circulates and experiences life at certain place, governed by certain political forces. This is what is present in the online environment of the group "Plantão da Cidade de Ouro Preto", that is, the particularities that permeate and challenge the municipality, the lives of its residents and the battles fought in that space. According to Maia et all (2016), understanding the particularities of each online environment of political conversation is understanding its logic and culture - what scholars will call collective semantics.

These are processes that resemble the way social movements - whichever they may be - build, over time and through the interaction of their participants, a certain ideological structure. The exchange of opinions, the mutual recognition regarding certain claims, the solidarity and the shared beliefs give rise to an identification. A meaning for the "we" in the collective action begins to exist. In online environments, these factors often invigorate exercises of citizenship and their effects in the midst of everyday life - and not only during electoral periods.

It was by analyzing the effects of communication technologies on social movements' routines that Rousiley Maia (2008) observed, for instance, the emergence of some phenomena, such as the effort to interpret different interests, the formation of collective identities, the political activism, the institutional clashes and the sharing of power, among other dynamics. This shows that expanded deliberative processes can contribute to the reproduction of the feeling of solidarity, to the formation of basic bonds and to the constitution of collective identities and subjectivities. To Marques and Maia (2008), what the digital environment does, in this sense, is to enable the expansion of meetings - which drives these processes.

In the local context - as it is the case of the city of Ouro Preto - political participation takes place, specially, through social exchanges, that is, the sharing of affections through testimonies and personal narratives, as it can be noticed in the "Plantão da Cidade". The group members experience the main problems of the municipality and accurately identify what effectively interests the population. This type 
of space, as emphasized by Rosseto, Carreiro and Reis (2015), allows, in general, any citizen to have "a general notion of the collective opinion on topics that are on the agenda", as well as "identifying profiles or websites of specific political causes in which it is possible to engage oneself", besides comparing their own opinions with other people's (p.4).

Obviously, it does not mean that, by broadening the possibilities of political participation, the Internet has constituted democratic paradises based on equality, justice, humanitarian principles or ethics. Communication technologies, we know, are also propagating anti-democratic, prejudiced and nefarious discourses. And they also contribute to misinformation. Good examples, widely reported by the press, are in the 2016 presidential election won by Donald Trump in the United States and by Jair Bolsonaro in Brazil in 2018 - both benefited by the large production and circulation of fake news. Fake news also influenced the Brexit referendum, which allowed the UK to formally leave the European Union in January $2020^{2}$.

It is by starting from this aspect, moreover, that Wilson Gomes (2008) pays attention to an important detail within this context: the one that, in order to understand the political participation of citizens, it is necessary to move away from the rhetoric of what is positive or negative. It is essential to understand how this participation can stimulate citizens to become involved with their city, state or country's political activity and, from that point, cultivate civic virtues. In this sense, what is clear - and already widely registered by the literature - is the importance of the processes that transform issues of collective interest into public debates, supporting the agenda and the government decisions.

\section{"Plantão da Cidade Ouro Preto" - From the visibility to the discursive dynamics}

Reflecting on the conversational dynamics, present in social networks, and their effects requires a close look at the discursive architecture of online spaces. In this section, we will briefly present the specificities of the group "Plantão da Cidade de Ouro Preto", created on April 30th, 2012. The first message posted by its founder explained the role to be fulfilled by that new online environment, as follows:

The main idea of this space is to inform, comment, question, justify and integrate with topics from Ouro Preto's daily routine, focusing on everything that happens, what is yet to happen or is about time it happened. The name "PLANTÃO" suggests a channel that is always

\footnotetext{
${ }^{2}$ See https://piaui.folha.uol.com.br/lupa/2018/09/24/brasil-eua-brexit-noticias-falsas/. Access: 12 jun. 2020.
} 
linked to any piece of news, which includes, besides the contexts, registry images of the facts. ${ }^{3}$

The group entered 2020 with 14,558 members and three moderators. The posts are presented as discursive exchanges on topics that are considered substantial for the citizens of Ouro Preto, especially with regard to health, education, maintenance of public spaces, transparency and public management accountability. It is also possible to find certain daily life narratives, reflection contents, as well as protests and convocations. This dynamic occurs through texts, videos, photos and mainly memes. The most curious element of this environment is the "summary" ${ }^{4}$ of Ouro Preto City Council's ordinary sessions, posted weekly, something quite peculiar regarding citizens' political participation. There are also comments about speeches and actions that reveal selfpromotion postures by some of the lawmakers or by the City Hall itself, as well and information regarding the region's cultural and religious monthly calendar.

The posts made by citizens in the group provide the sharing of important information about the city and its routine - on the streets and within the institutions as well as dialogues that contribute to the understanding and evaluation of local problems. The contents usually guide and sometimes mobilize the political actors responsible for leading certain processes related to local administration. Many demands from the residents gain visibility - demands that, otherwise, could be ignored. Thus, the posts do not have the objective to "inform", in the journalistic sense, but, effectively, to experience a dialogical practice, in which "a conversation among many creates thought" (BENTES, 2015, p. 12).

Just as it happens in offline spaces, the citizens who attend this platform often develop a sense of belonging, affective ties and proximity. In this sense, there is an expansion of the social circle (BARROS; CARREIRO, 2015). The "Plantão da Cidade" presents these particularities that provide the engagement of participants in sociopolitical debates that reverberate in the institutional spheres of the municipality of Ouro Preto. The conversations held between its members affect, particularly, the City

3 Group "Plantão da Cidade Ouro Preto". Available at: <https://ptbr.facebook.com/groups/228600653911959/>. Accessed on 30 Sep. 2019.

${ }^{4}$ A citizen of Ouro Preto makes a weekly summary of Ouro Preto City Council's ordinary meetings. She presents, in a subjective and dynamic way, the report of the main ideas discussed, originated from the motions and representations that are filed, and the recommendations on the agenda. The summary gives an idea of the political situation experienced by the municipality. The text refers to the themes and votes under discussion at the City Council, with an emphasis on basic issues of popular interest - especially in the health, education, safety, accountability and urban cleaning areas. 
Council and the City Hall. More than once, themes raised by the group guided the discussion of parliamentarians in plenary, for example.

Fact is that the members of this group save part of their daily routine only to address issues that affect them as residents of Ouro Preto. This exchange process, generally inspired by personal testimonies, is marked by an interpretative reframing of situations and events that interfere in the scenarios and daily life of the city and its population. The analysis undertaken from the observed dialogues shows important aspects in this sense, as it will be seen below.

\section{Analysis and indicators}

The investigative path defined to uncover the way citizens of Ouro Preto take property of the "Plantão da Cidade" group - anchored to the discussion of the themes that are put on the agenda there, mainly focused on public policies aimed at the municipality - was divided into some stages. The first one was based on exploratory navigation, with the purpose of identifying the particularities that cross publications and conversational dynamics in that environment. The analytical corpus, then, contemplated three selected posts, based on the expressive discursive potential they generated during the investigation period. Together, these posts rendered a total of 219 comments examined. They are: (1) the deconstruction, by a municipal guard of Ouro Preto, in 2019, during the celebrations of the Holy Week, of a sawdust carpet assembled in honor of the councilwoman Marielle Franco, shot dead on March 14, 2018, at Estácio, Downtown Rio de Janeiro; (2) Conflicts between residents and parliamentarians of the municipality, due to the health sector's outsourcing policy; (3) the complaint about the neglection of a sports complex known as "Campo do Bairro Água Limpa" by the municipal government. 


\begin{tabular}{|c|c|c|c|c|c|c|}
\hline POST & TOPIC & DATE & IMAGE & LIKES & COMMENTS & SHARINGS \\
\hline 1 & $\begin{array}{l}\text { Holly } \\
\text { Week's } \\
\text { sawdust } \\
\text { carpet }\end{array}$ & $\begin{array}{l}21 \mathrm{apr} \\
2019\end{array}$ & No & 62 & 63 & 4 \\
\hline 2 & $\begin{array}{c}\text { Outsourcin } \\
\text { g of Ouro } \\
\text { Preto's } \\
\text { Health } \\
\text { Sector }\end{array}$ & $\begin{array}{l}26 \mathrm{apr} \\
2018\end{array}$ & $\begin{array}{l}\text { Yes } \\
\text { (photo) }\end{array}$ & 42 & 99 & 9 \\
\hline 3 & $\begin{array}{c}\text { "Campo do } \\
\text { Água } \\
\text { Limpa" } \\
\text { Sports Field }\end{array}$ & $\begin{array}{l}30 \text { sep } \\
2019\end{array}$ & $\begin{array}{l}\text { Yes } \\
\text { (video } \\
\text { from } \\
\text { within the } \\
\text { field's } \\
\text { locker } \\
\text { room }\end{array}$ & 42 & 57 & 16 \\
\hline
\end{tabular}

Source: Research "Plantão da Cidade Ouro Preto" - Analytical Table

The next stage was the examination of these comments, considering, above all, the discursive dynamics and resources used by the participants during the conversation. At that moment, we established the categories of analysis, defined in accordance with the theoretical-methodological proposal of Marques (2011) and Carreiro (2017). The table below organizes the analytical process and was used to verify the comments in the three posts selected and described above.

\begin{tabular}{|c|c|c|}
\hline CATEGORIES & DESCRIPTION & $\begin{array}{l}\text { RELATED } \\
\text { OPERATORS }\end{array}$ \\
\hline $\begin{array}{l}\text { WAY OF PRESENTING THE } \\
\text { COMMENT }\end{array}$ & $\begin{array}{l}\text { It has the purpose of } \\
\text { defining the way the } \\
\text { participant presents } \\
\text { him/herself in the } \\
\text { discussion. }\end{array}$ & $\begin{array}{l}\text { - Declaration/affirmation } \\
\text { - Opposite point of view } \\
\text { - Enlightenment } \\
\text { - New approach } \\
\text { - Questioning }\end{array}$ \\
\hline
\end{tabular}




\begin{tabular}{|c|c|c|}
\hline COMMENT'S OBJECTIVE & $\begin{array}{l}\text { This category seeks to } \\
\text { understand the comment's } \\
\text { role in the discussion, } \\
\text { when facing the initial } \\
\text { comment or the role of the } \\
\text { arguments that make part } \\
\text { of the conversation. }\end{array}$ & $\begin{array}{l}\text { - Neutral } \\
\text { - New point of view } \\
\text { - Support } \\
\text { - Opposition }\end{array}$ \\
\hline $\begin{array}{l}\text { ARGUMENTATIVE } \\
\text { RESOURCES }\end{array}$ & $\begin{array}{l}\text { This category seeks to } \\
\text { know the elements that } \\
\text { reinforce the } \\
\text { argumentation and } \\
\text { complement the comment. }\end{array}$ & $\begin{array}{l}\text { - Information source } \\
\text { - Personal testimony } \\
\text { - None } \\
\text { - Irony } \\
\text { - Humour }\end{array}$ \\
\hline $\begin{array}{l}\text { TECHNICAL } \\
\text { RESOURCES } \\
\text { USED }\end{array}$ & $\begin{array}{l}\text { It refers to the use of } \\
\text { elements available in the } \\
\text { platform of the Plantão da } \\
\text { Cidade group on } \\
\text { Facebook. }\end{array}$ & $\begin{array}{l}\text { - Text } \\
\text {-Image } \\
\text {-Meme } \\
\text {-Video } \\
\text {-Link }\end{array}$ \\
\hline $\begin{array}{lrr}\text { RELATION } & \text { TO } & \text { THE } \\
\text { MUNICIPAL } & & \text { PUBLIC } \\
\text { AUTHORITY } & & \end{array}$ & $\begin{array}{l}\text { It refers to the purpose of } \\
\text { the comment in relation to } \\
\text { the municipal public } \\
\text { authority. }\end{array}$ & $\begin{array}{l}\text { - Positive } \\
\text { - Negative } \\
\text { - Neutral (no relation to } \\
\text { the municipal public } \\
\text { authority) }\end{array}$ \\
\hline
\end{tabular}

Source: Research "Plantão da Cidade Ouro Preto" - Analytical Table

Once the categories were defined, the research's next stage was initiated, which consisted of the careful reading of all comments, considering the dynamics of the debate on the agenda and the resources used by the participants. By examining the conversations in the "Plantão da Cidade", starting from the categories worked, the idea was to identify the specificities of the group, the way citizens articulate themselves when discussing with each other, the general functioning of the debate, the resources used for the argumentation and the positioning of the citizen before the action of the municipal public authority.

The analysis of all the material organized provides an expanded and curious view of the particularities of the political conversation in the "Plantão da Cidade de Ouro 
Preto". The data - which, in the graph below, can be compared with each other - evidence the ways in which the citizens who participate in the group appropriate this space, in order to publish, read and react to the analyzed posts.

Figure 1 - Graph - Way of presenting the comment

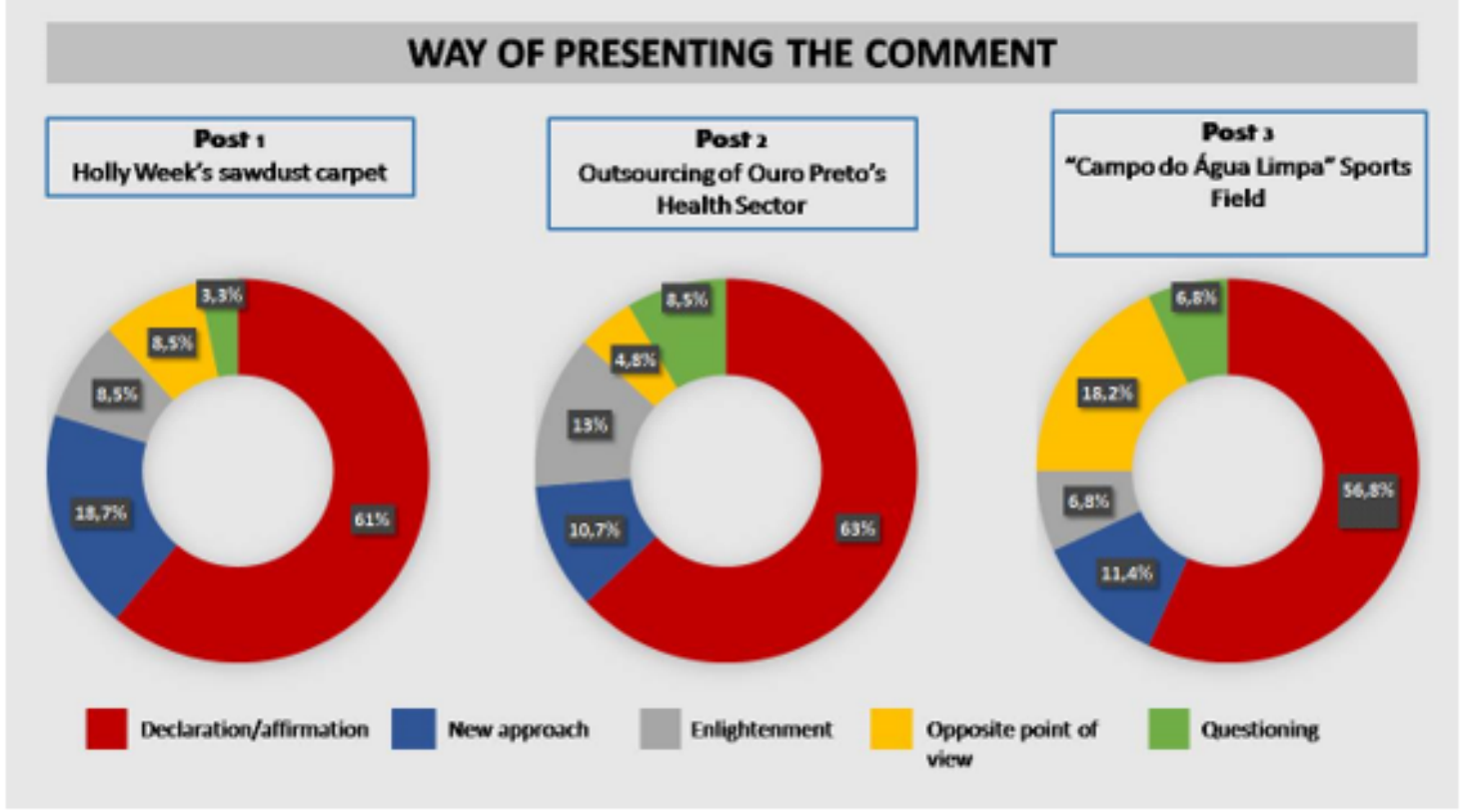

Source: Research Data, 2019.

Figure 2-Graph - Comment's objective

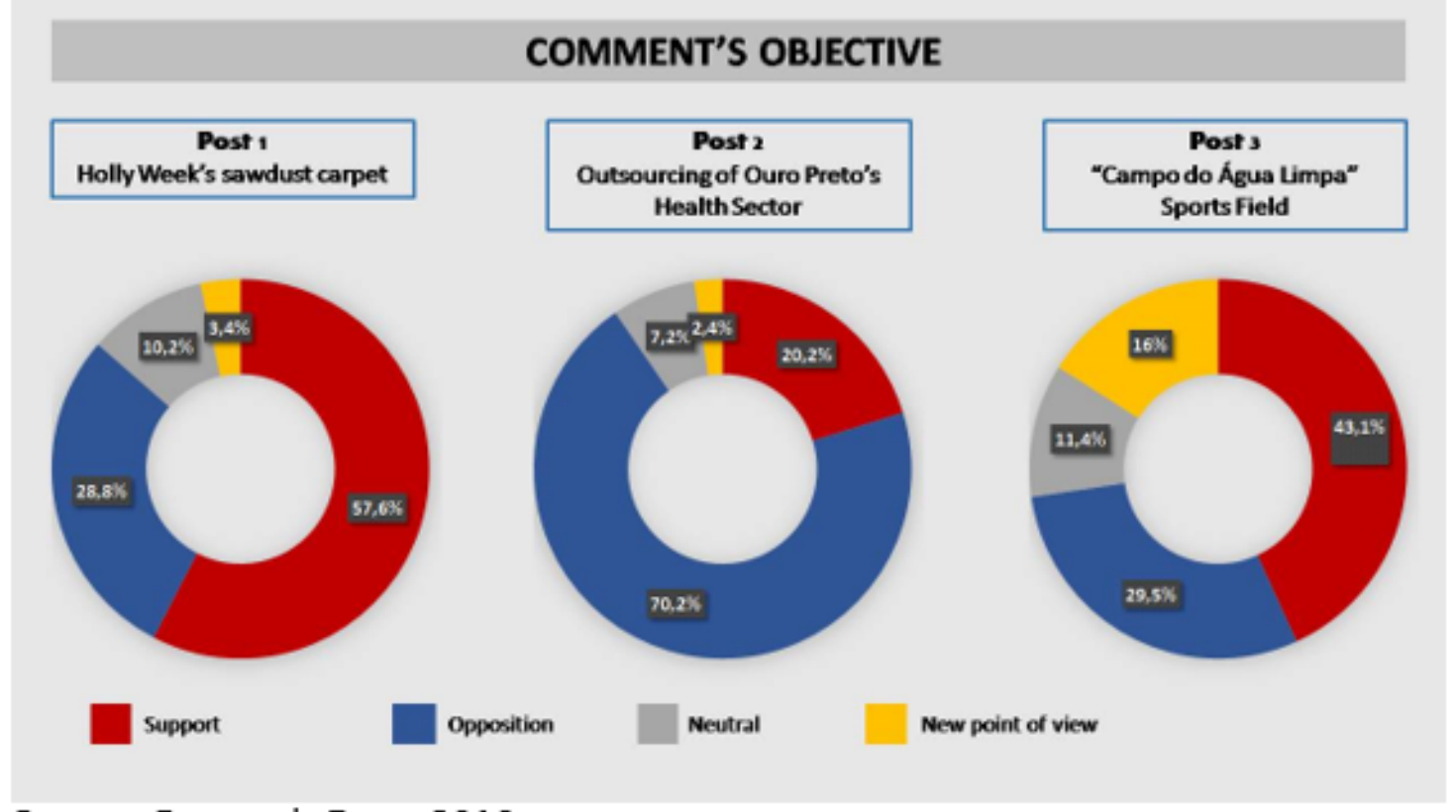

Source: Research Data, 2019. 
Filgure 3 - Graph - Argumentative Resources

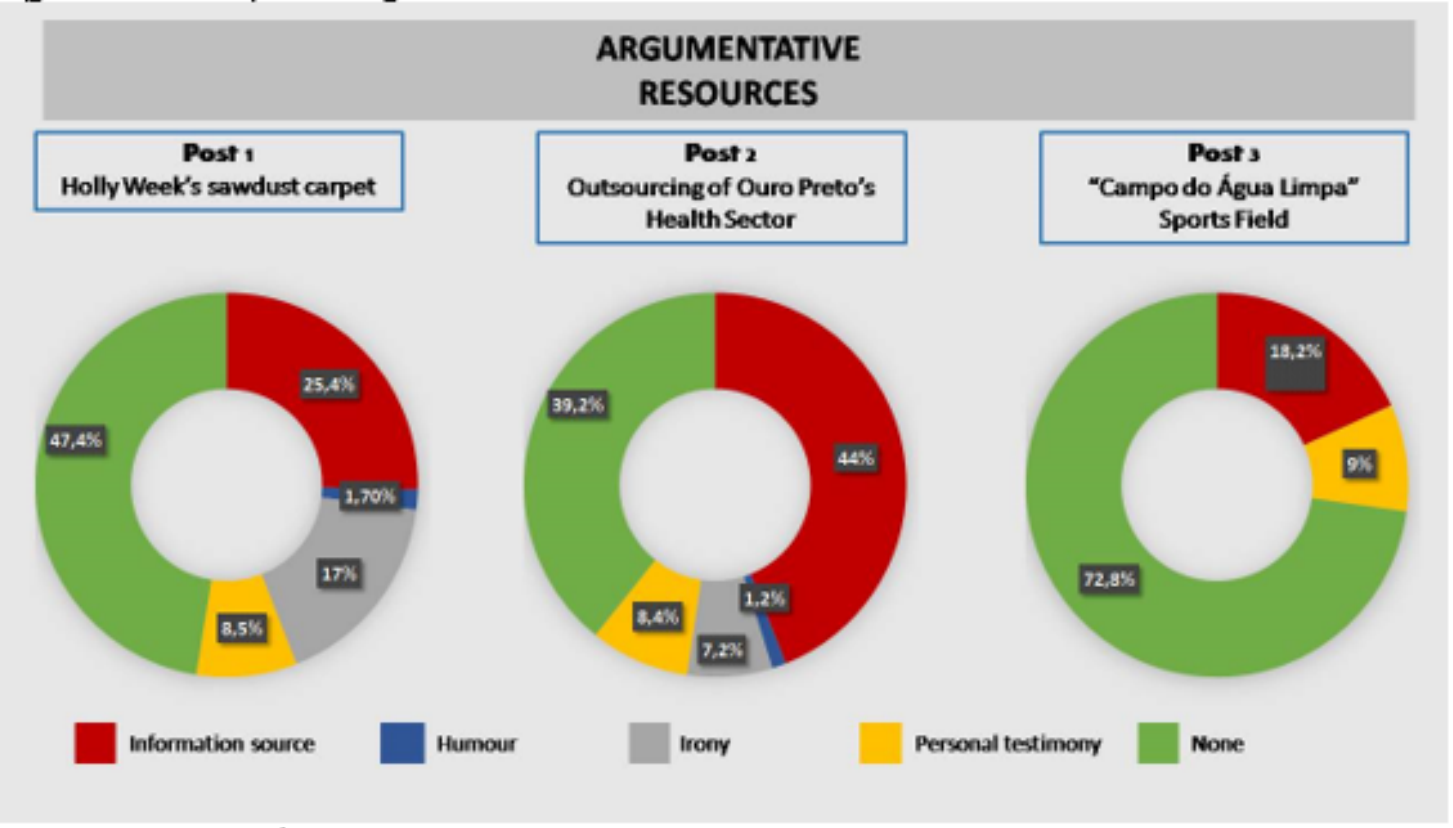

Source: Research Data, 2019.

Figure 4-Graph - Technical Resources Used

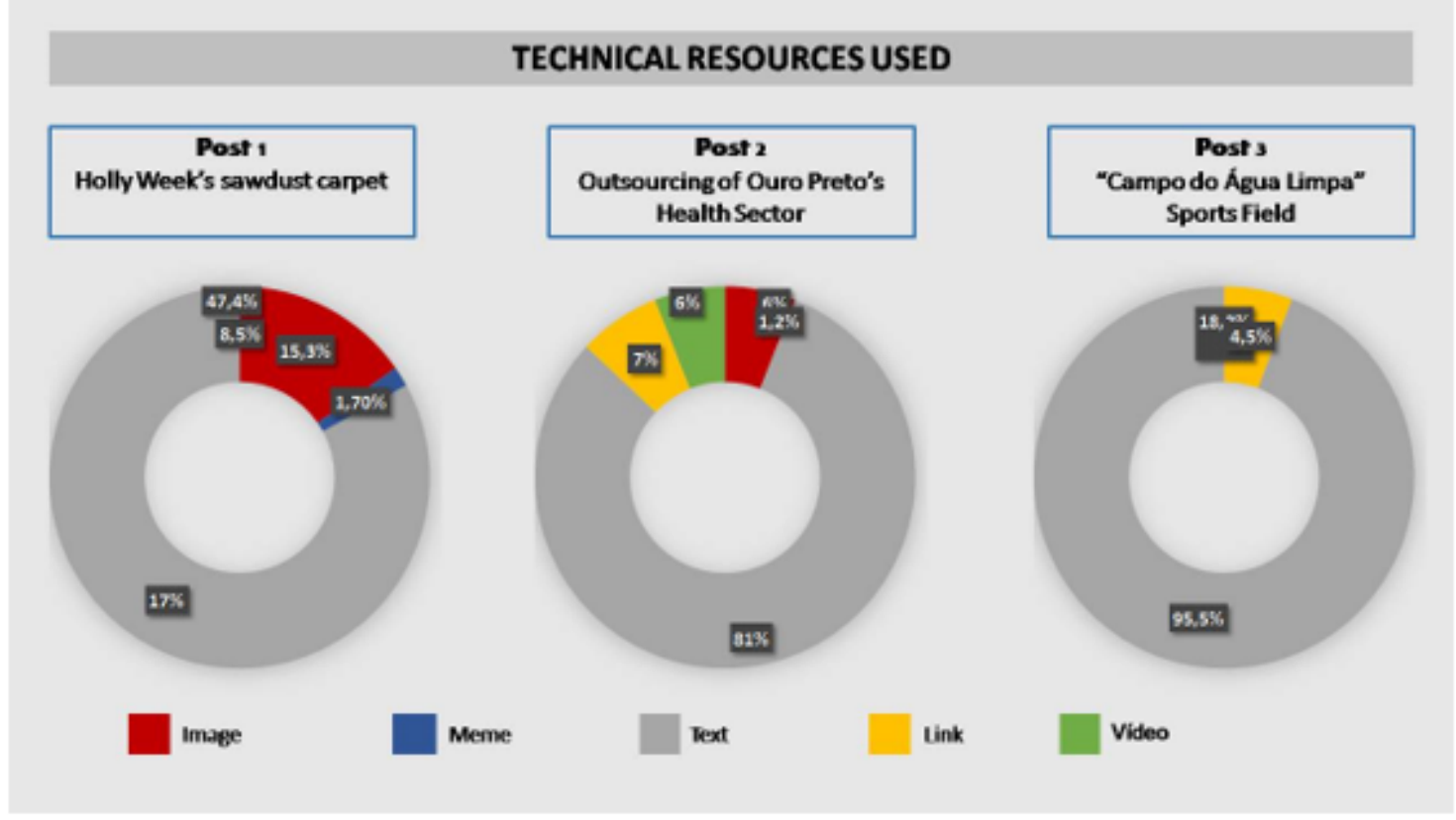

Source: Research Data, 2019. 
Figure 5-Graph - Relation to the Municipal Public Authority

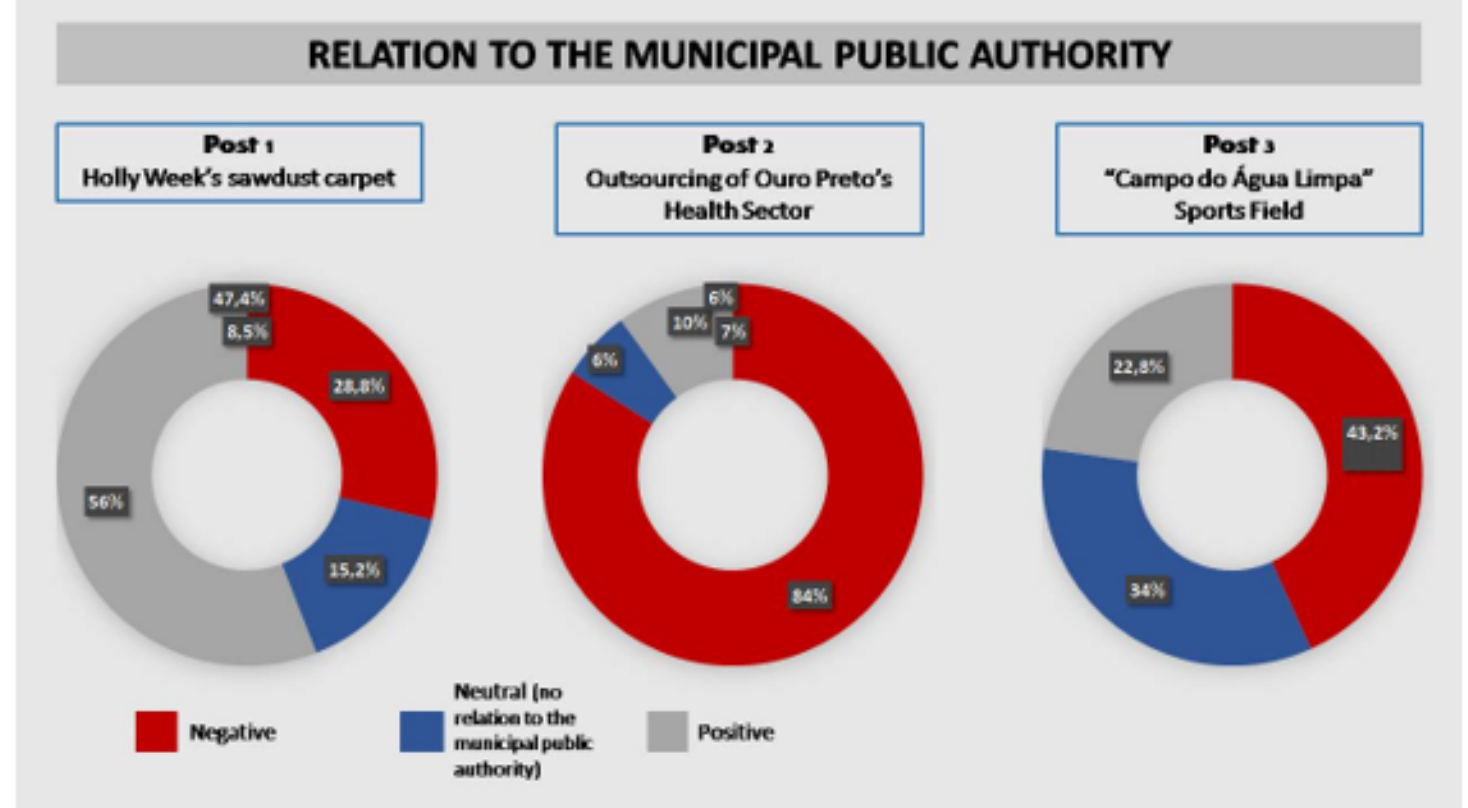

Source: Research Data, 2019.

In the graphs extracted from comments' codification, it is possible to notice how the themes related to the politics of Ouro Preto addressed in this Facebook environment are valued as problems based on the demands for public policies (as it is the health sector's outsourcing case and the sports fields' case) and on the issues crossed by the local culture's nuances, strongly linked to the great power and influence still exercised by the Catholic Church in the municipality (as it is case of the carpet that pays homage to Marielle Franco). In either case, the discussion emerges, to a large extent, detached from mere party disputes. The collectivity's most pragmatic interests - and the experience of cultural traditions, especially those of a religious nature - emerge above ideological interests, although these are present and can be observed in the field of the subjectivities that are characteristic of discursive dynamics.

Another aspect revealed is in the accomplishment of this conception of deliberation as a process initiated from the assimilation of the issues in question - which is beyond the decision-making itself. It emerges, in this online environment, as a communication social process that seeks, mainly, the elucidation of the themes listed for the debate. Here, deliberation emerges from its sociological perspective, and not due to its normative character. The "Plantão da Cidade" ensures, this way, real debate opportunities and collective actions, especially in the municipal public sphere, where the relationship between the citizen and government power is closer. 
This empirical look at a Facebook group that influences residents, city councilors and public authorities from the municipality of Ouro Preto is an attempt to broaden the field of debates about the political conversation in online environments. It allows us to think of these platforms as an important place to observe the discursive dynamics that the Internet provides, but also as a space of powerful debates to influence the actions of those who represent citizens in the governmental sphere, especially in smaller cities. Reflecting on the political conversation from these platforms is just one of the ways to glimpse the world and its dialogues - an increasingly challenging exercise.

But to think about the influence of these platforms on the common citizen's daily life, in small or large localities, is not enough. We must also be focused on the effects of this influence on people's lives in different societies spread across the continents. And it is important to aim, above all, at the way the conversations observed in the online universe increasingly provide this double experience - affective and political.

These are issues that acquire renewed contours in moments of confrontation like this, marked by pandemics, hate speeches and authoritarian regimes. In these scenarios, online platforms are accessed not only for information sharing, but also - and mainly to disseminate fake news and prejudiced speeches. The second millennium elapses in the midst of one of the greatest crises faced by humanity, subject to dark scenarios, due to the death of thousands of people - if not by illness, by violence, especially the poorest segments of the populations. In this context, reflecting on the field of political conversation in digital environments - but also on the real possibilities of political participation of the common citizen in these spaces - can stimulate another important discussion, this time inspired by two movements that we consider fundamental to humanity: the possible displacements of power in the political sphere, and the latent displacements of power in societies.

\section{References}

ALMADA, Maria Paula; CARREIRO, Rodrigo; BARROS, Samuel; GOMES, Wilson.

Democracia digital no Brasil: obrigação legal, pressão política e viabilidade tecnológica. Matrizes, São Paulo, v. 13, n.3, p- 161-181, set/dez.2019.

BARROS, Samuel; CARREIRO, Rodrigo. A discussão pública e as redes sociais online: o comentário de notícias no Facebook. Revista Fronteiras - Estudos Midiáticos, São Leopoldo, v. 17, n. 2, p. 174-185, 2015.

BENTES, Ivana. Mídia-Multidão: estéticas da comunicação e biopolíticas. Rio de Janeiro: Mauad X, 2015. 
CARREIRO, Rodrigo. A Discussão Política Em Rede: Um Estudo Sobre a Divergência Política no Facebook. 2017. 246 f. Tese (Doutorado em Comunicação e Cultura Contemporâneas) - Universidade Federal da Bahia, Salvador, 2017.

CHAGAS, Viktor et ali. A Política dos Memes e os Memes da Política: proposta metodológica de análise de conteúdo de memes dos debates eleitorais de 2014. Intexto. N. 38, 2017.

GOMES, W. Da discussão à visibilidade. In: GOMES, W.; MAIA, R. Comunicação e democracia: problemas e perspectivas. São Paulo: Paulus, 2008. p. 117-162.

GOMES, W. Internet e participação política. In: GOMES, W.; MAIA, R. Comunicação e democracia: problemas e perspectivas. São Paulo: Paulus, 2008. p. 293-325.

GOMES, Wilson. A democracia digital e o problema da participação civil na decisão política. Fronteiras-estudos midiáticos, São Leopoldo, v.7, n.3, p. 214-222, 2005.

GOMES, Wilson. A democracia digital e o problema da participação civil na decisão política. Fronteiras-estudos midiáticos, São Leopoldo, v.7, n.3, p. 214-222, 2005.

GOMES, Wilson. Participação política online: questões e hipóteses de trabalho. In: GOMES, W.; MAIA, R. C. M.; MARQUES, F. P. J. A. Internet e Participação Política no Brasil. Porto Alegre: Sulina, 2011. cap. 1, p. 19-35.

GRAHAM, T. Needles in a Haystack: a new approach for identifying and assessing politial talk in non-political discussion forums. In: Jav-Host - The Public. v. 15, n. 2, p. 1736, 2008.

HABERMAS, J. Direito e Democracia: entre facticidade e validade. v. I e II. Tradução de F. Siebeneichler. Rio de Janeiro: Tempo Brasileiro, 1997.

KIES, R. Promises and limits of Web-deliberation. Nova York: Palgrave Macmillan, 2010.

LIMA, Venício. Sobre a cultura do silêncio. 2017. Disponível em:

<https://www.cartamaior.com.br/?/Editoria/Midia-e-Redes-Sociais/Sobre-acultura-do-silencio-1-/12/38974> Acesso em: 20 mar. 2019.

MAIA, R. C. M. Conversação Cotidiana e deliberação. In: GOMES, W.; MAIA, R. C. M. Comunicação e Democracia: problemas \& perspectivas. São Paulo: Paulus, 2008.

MARQUES, A. Aspectos teórico-metodológicos do processo comunicativo de deliberação online. In: Revista Brasileira de Ciência Política, Brasília, n. 6, p. 19-40, jul. /dez. 2011.

MATOS, E; BARROS. S; CARREIRO, R. "Ouvindo nosso bairro": um estudo sobre a participação política local por meio de multiplataformas. in: Comunicação e política: interfaces em esferas regionais. São Luís: EDUFAMA, 2019. p. 203-227. 
ROSSETTO, G. P. N.; CARREIRO, R.; REIS, L. Conversação Política no Facebook: um estudo sobre a crise da água no Brasil. In: Congresso o Compolítica, 16. Rio de Janeiro. Anais... Rio de Janeiro: PUC-Rio, 2015.

STROMER-GALLEY, Jennifer. Decoding deliberation online. In.: Second Conference on Online Deliberation, Palo Alto, California, Anais... California: Online Deliberation, mai. 2005. 


\section{Crevisto Observatório}

RESUMO:

O objetivo desse artigo é discutir a participação política dos cidadãos mediada pelas tecnologias de comunicação. Procuramos compreender os potenciais cenários e meios para a promoção da participação cidadã no universo do poder público. A investigação se deu a partir da observação de um espaço específico no Facebook: o grupo Plantão da Cidade, criado no município de Ouro Preto para viabilizar discussões de cunho político. $O$ exame proposto evidencia as possibilidades oferecidas pelo ambiente online para assegurar a participação política do cidadão comum nas decisões da gestão municipal e a mobilização de ações comunitárias locais.

PALAVRAS-CHAVE: Cidadania. Deliberação. Facebook. Participação política. Redes sociais.

\section{RESUMEN:}

El propósito de este artículo es discutir la participación política de los ciudadanos mediada por las tecnologías de la comunicación. Buscamos comprender los escenarios posibles y los medios para la promoción de la participación ciudadana en el universo del poder público. La investigación ocurre a partir de la observación de un espacio especifico en Facebook: el grupo Plantão da Cidade, creado en la ciudad de Ouro Preto para viabilizar discusiones de naturaleza política. El análisis propuesto destaca las posibilidades ofrecidas por el ambiente online para garantizar la participación política del ciudadano común en las decisiones de la gestión municipal y la movilización de acciones comunitarias locales.

PALABRAS-CLAVES:

Deliberación; Facebook;
política; Redes sociales.

Ciudadanía; Participación 